\title{
Autonomous fiber-optic gas monitoring system with thermoelectric power supply
}

\begin{abstract}
This paper presents the concept of an autonomous measuring instrument powered by a locally accessible source of heat with a contact surface area of over a dozen or several dozen $\mathrm{cm}^{2}$ and a temperature higher or lower than the ambient temperature. The design and construction of the measuring device will be based on two modules developed and constructed in the course of previous work: a dedicated low-power thermoelectric generator and luminescent fiber-optic detector. The system can be additional equipped with a wireless transmission module. The studies show that, due to the power supply and photoluminescent measurement system with high stability of the operating point, this device will be capable of continuous operation without maintenance for many months.
\end{abstract}

Key words: gasometry, thermocouple, nanotechnology

\section{INTRODUCTION}

The commissioning of new equipment in a measuring network under industrial conditions requires the provision of adequate power and communication interfaces. In many applications, it is embarrassing because of the need for new power and teletransmission wires (after the installation project). The best solution for low-power measuring devices that work on the ground and in open space is the use of wireless transmission and a hybrid power supply based on batteries and photovoltaic cells. This solution can be partially used in underground mines, except that the photovoltaic cell will be replaced by a thermoelectric cell. The simplest thermoelectric module, which converts heat flux into electricity, is based on the Seebeck effect. Elements of this type are commonly used in small refrigeration units, where they occur in the Peltier phenomenon (which is the reverse of the Seebeck phenomenon). The same trade name module ("Peltier Module") can be used as either a cooling element (one side of a module cools and another heating up) and an electric generator as a result of the flow of heat flux through the module due to an externally forced temperature difference between its pages. The Peltier and Seebeck phenomena have been known in the field of physics since the beginning of the 19th century; they are discussed more extensively in works [1, 2-4].

The measuring part of the proposed device will be based on a fiber-optic detector. It is a completely non-electric element at the place of measurement, which is very important when working in an explosive atmosphere.

In this paper, we present a detector of oxygen content in the atmosphere - OSE (Oxygen Sensor Effect). Its operating principle uses the unique properties of nanocrystalline zirconium dioxide doped with europium, obtained by microwave hydrothermal synthesis. More information about the properties and obtaining the nanomaterial are included in paper [5].

The detection material $-\mathrm{ZrO}_{2}: \mathrm{Eu}^{3+}$ nanoparticles struck by a UV light beam at a $405 \mathrm{~nm}$ wavelength, and the UV beam is diffused. In addition to UV in the reflected spectrum, there are red and near-infrared signals from the luminescence in a range of about 580-720 nm, whose intensity depends on the concentration of oxygen. An increase in the oxygen 
content of the gas/atmosphere mixture results decrease in photoluminescence intensity. The presented method of measuring oxygen concentration has been patented by Polish and European patents [6,7].

\section{CONCEPT OF FIBER-OPTIC SENSOR POWERED BY THERMOELECTRIC GENERATOR}

Figure 1 shows a block diagram of a thermoelectric cell measuring device with an external measuring chamber connected to two optical fibers. In the course of previous work, demonstrators of the most-important modules of the device were constructed, including:

- a thermoelectric generator based on the Seebeck phenomenon with a dedicated, stabilized DC/DC converter,

- a fiber-optic photoluminescent gas detector.

The proposed fiber-optic detector is a low-power consumption measuring system that can cooperate with the constructed thermoelectric generator.

The other modules (radio transmitter and low-power microcontroller) will be based on commercially available components and standard equipment used in industrial equipment. Additionally, the voltage stabilizer integrated in the inverter has a SuperCap-type capacitor characterized by high electrical capacitance. Its presence will allow the device to obtain instantaneous electrical power many times greater than the value of the continuous power of the thermoelectric cell (e.g., during radio transmission of data packets in increased power/range mode). The SuperCap exploitation will be controlled by the microcontroller through power transistors. The blue frame on the diagram in Figure 1 indicates the stationary part of the unit that will be installed/built in a place where it is possible to obtain a difference in temperature and heat flux.

A measuring chamber contains detection material that is connected to a stationary member via a fiberoptic cable, which may be several meters or even kilometers in length depending on the fiber type used. The experimental version of the system uses a multi-beam optical fiber cable with a length of about two meters. The UV wave is produced by a UV LED 405-nm diode.

The detection part consists of two semiconductor photodetectors, preceded by optical filters. The first detector measures light in the UV area that has been previously dispersed in the measuring chamber on the detection material. The sensitivity area of the second detector ranges from $580 \mathrm{~nm}$ to $640 \mathrm{~nm}$ or $600 \mathrm{~nm}$ to $640 \mathrm{~nm}$ and is associated with photoluminescence produced in the detection material. Thanks to the UV level measurement, a reference signal is provided that allows the instrument to autocalibrate at almost any time.

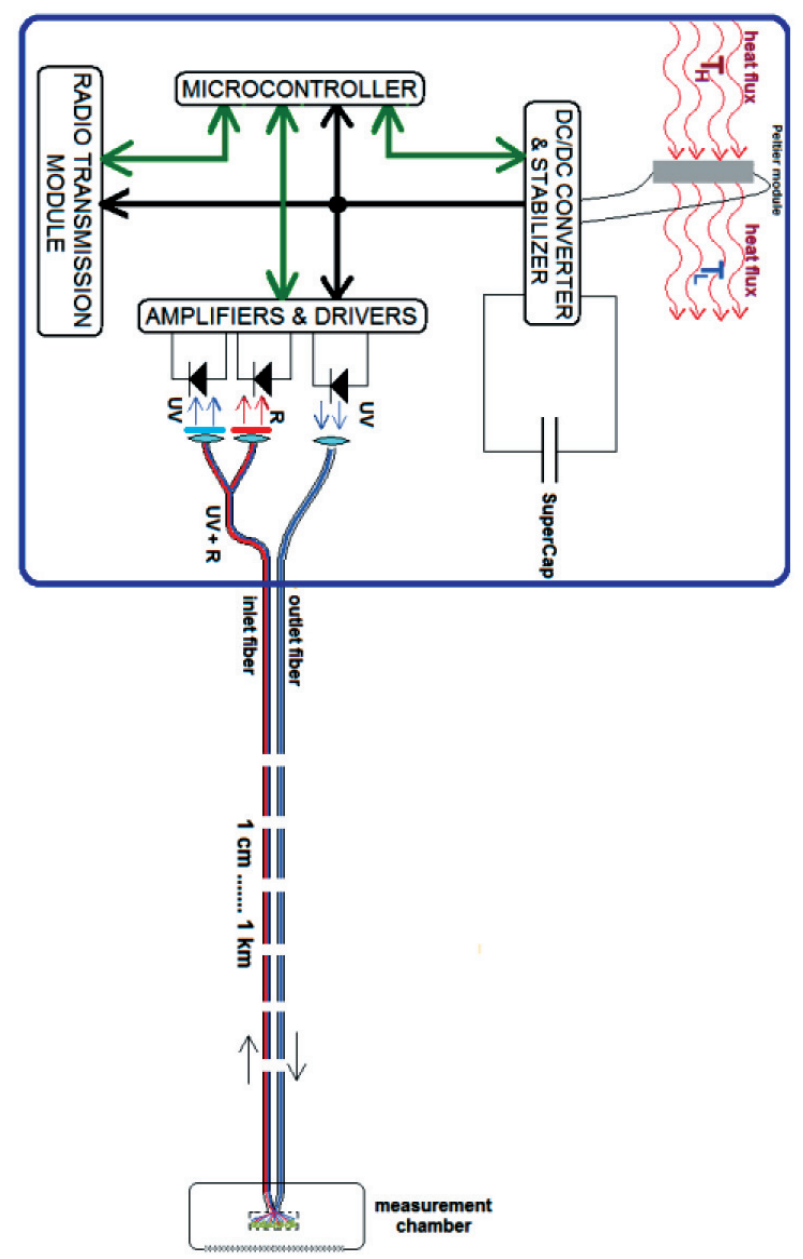

Fig. 1. Block diagram of measuring device powered by thermoelectric cell with outer fiber-optic measuring chamber

\section{THERMOELECTRIC GENERATOR BASED ON PELTIER MODULE}

The construction of the thermoelectric generator has been based on commercially available Peltier modules, which are mainly intended for refrigeration equipment. Three modules (each with $30.0 \mathrm{~mm} \times 30.0 \mathrm{~mm} \times 3.3 \mathrm{~mm}$ dimensions) were electrically connected in a series structure. Figure 2 shows an infrared image of the mea- 
suring system to determine the electrical characteristics of a single module as an electric generator. Based on the images in Figure 2, the temperature of both sides of the Peltier module (which was the Seebeck phenomenon) was measured in each case.
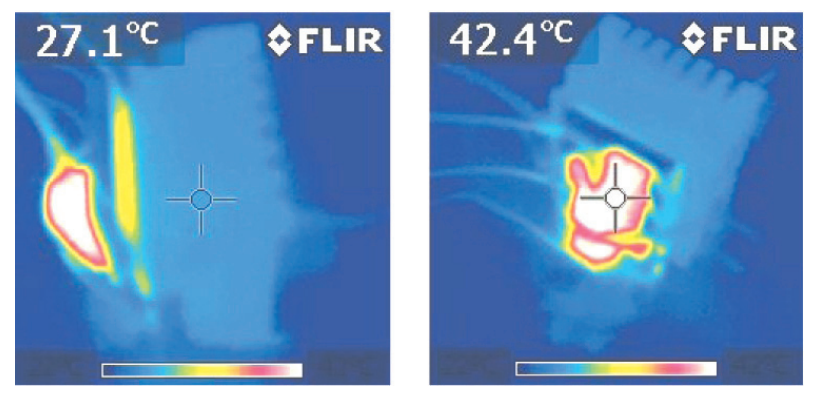

Fig. 2. Infrared images of measuring system for determining electrical characteristics of single module as electric generator

The chart in Figure 3 shows the electrical power output of a single Peltier module operating as a thermocouple for various load resistances and a temperature difference between the Peltier module sides of $30.3^{\circ} \mathrm{C}$.

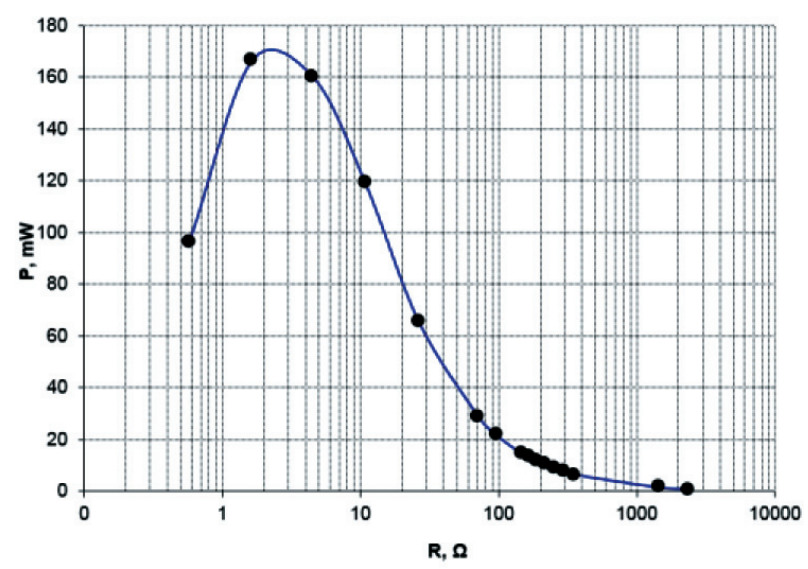

Fig. 3. Electrical power generated by Peltier module during conversion of heat energy to electrical energy for different load resistance (results for temperature difference between module sides $30.3^{\circ} \mathrm{C}$ )

The highest output power is obtained for a load resistance of about $2-3 \Omega$. It was necessary to develop a dedicated stabilized DC/DC converter equipped with a SuperCap energy cartridge to keep the module working around its maximum electrical power.

The maximum electrical power obtained from the Peltier module per unit of its transverse surface (through which perpendicularly penetrates the heat flux) during operation as a thermocouple depends strongly on the temperature difference between its sides (as illustrated in Fig. 4). The single Peltier module surface area is $9 \mathrm{~cm}^{2}$ (one side).

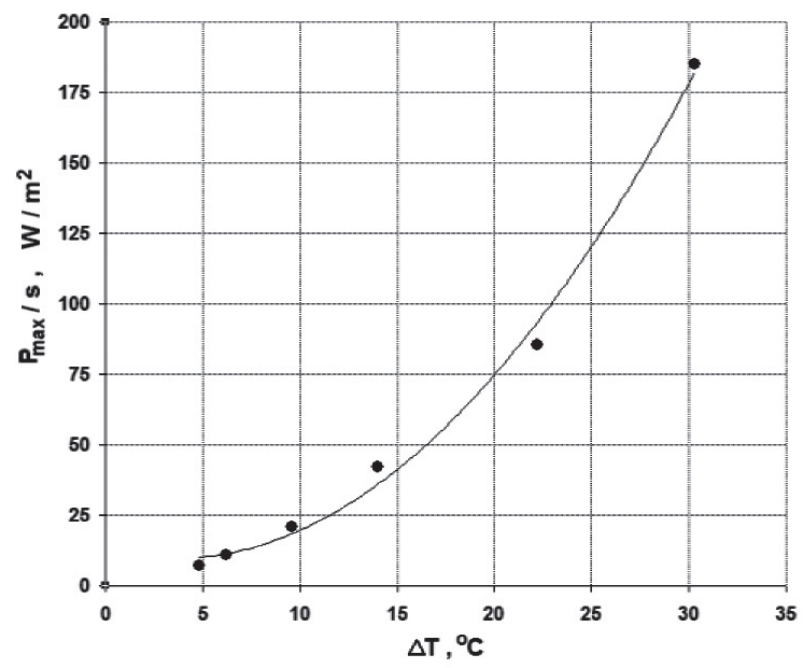

Fig. 4. Electrical power produced per surface area unit of Peltier module in which conversion of heat energy to electricity occurs depending on temperature difference between sides of module

The measurements results indicate that for a temperature difference of about $30^{\circ} \mathrm{C}(\mathrm{K})$ between the sides of the Peltier (Seebeck) module and the current technological level of the manufactured modules, the electric power is over 180 Watts. The electrical power produced by the module surface area unit may approximate to the second-degree polynomial or the following power function:

$$
\frac{P_{\max }}{s}=A \cdot \Delta T^{2}+B \cdot \Delta T+C
$$

where:

$$
\begin{aligned}
& A=0.24(0.04) \mathrm{W} /\left(\mathrm{m}^{2} \cdot \mathrm{K}^{2}\right), \\
& B=-1.7(1.5) \mathrm{W} /\left(\mathrm{m}^{2} \cdot \mathrm{K}\right), \\
& C=13(10) \mathrm{W} / \mathrm{m}^{2}
\end{aligned}
$$

$$
\frac{P_{\max }}{s}=A \cdot \Delta T^{B}
$$

where:

$$
\begin{aligned}
& A=0.16(0.08) \mathrm{W} /\left(\mathrm{m}^{2} \cdot \mathrm{K}^{\mathrm{B}}\right), \\
& B=2.07(0.16) \log _{\mathrm{k}}\left(\mathrm{W} \cdot \mathrm{m}^{2} \cdot \mathrm{A}^{\circ 1}\right) .
\end{aligned}
$$

Considering the high uncertainty of the values of some coefficients in Equations (1) and (2), it can only be stated that both matches clearly indicate the nature of dependency $\frac{P_{\max }}{s} \sim \Delta T^{2}$. 


\section{PHOTOLUMINESCENT GAS DETECTOR}

The measuring chamber is a completely non-electric device. Figure 5 shows the chamber demonstrator, which is the starting point for the construction of its industrial version. The analyzed gas enters the detection cavity via a 4-mm-diameter tube. This process can be forced by injection of a gas mixture or by self-diffusion. Depending on the alignment of the calibration elements of the chamber, the detection process is performed in a cavity with a volume of about $1 \mathrm{~cm}^{3}$. The industrial version of the device will radically reduce the external dimensions of the chamber and replace the intake tube to a flat ceramic filter, which will significantly reduce the diffusion time of the gas entering the chamber. The material of which the chamber housing has been made (stainless steel) will be finally adapted to the requirements of explosive atmospheres; i.e., any impact on the enclosure of the device cannot generate a spark. To the chambers of Figure 5, two groups of optical fibers were connected in accordance with the idea in Figure 1.

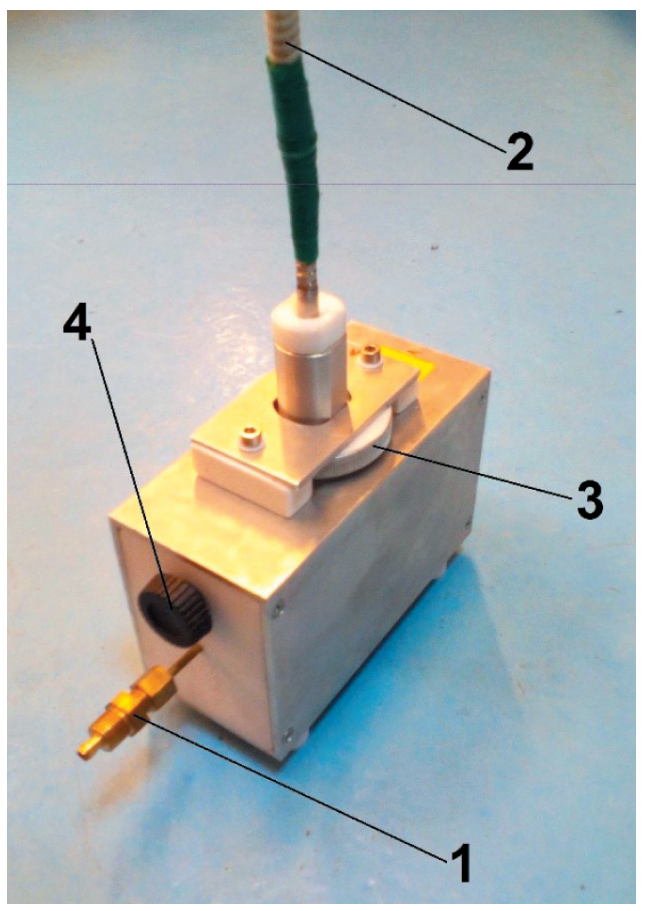

Fig. 5. Measuring chamber: 1 - inlet of measured gas; 2 - fiber-optic armature; 3 and 4 - calibration screws. External dimensions of rectangular part of chamber: $170 \mathrm{~mm} \times 100 \mathrm{~mm} \times 70 \mathrm{~mm}$

They are included in one armor - apparently, only one fiber is connected. The detection material $-\mathrm{ZrO}_{2}$ nanoparticles: $\mathrm{Eu}^{3+}(5 \% \mathrm{~mol})-$ is a tablet (obtained by compression) with a diameter of $7 \mathrm{~mm}$ and thickness of $0.2 \mathrm{~mm}$. The nanoparticles contained in the pellet have an average size of about $10 \mathrm{~nm}$. UV light causes photoluminescence in the detection material, which is dependent on the level of oxygen.

Figure 6 shows an example of the luminescence signal produced in the detection material placed in the chamber in Figure 5 and illuminated with a wavelength of $405 \mathrm{~nm}$.

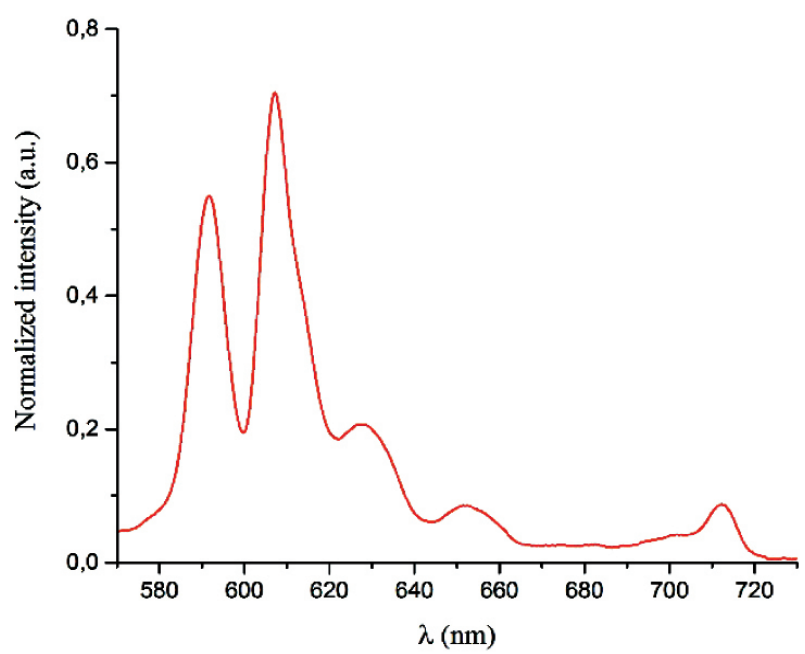

Fig. 6. Luminescence signal of $\mathrm{ZrO}_{2}: \mathrm{Eu}^{3+}$ tablet obtained in laboratory atmosphere

(without gas flow, at room temperature) [5]

The location of the individual extremes corresponds to the colors red and near infrared. This is due to the electron transitions characteristic for $\mathrm{Eu}^{3+}$ ions deposited in the $\mathrm{ZrO}_{2}$ nanocrystalline matrix.

The height of the peaks and value of the surface area under the curve in Figure 6 in the assumed range (the luminescence intensity integral) depends on the concentration of oxygen, and the optical signal is measured in the stationary part of the device. Depending on the optical filter available, a measurement wavelength range of $580 \mathrm{~nm}$ to $640 \mathrm{~nm}$ or $600 \mathrm{~nm}$ to $640 \mathrm{~nm}$ was used $[8,9]$.

The characteristics in Figure 7 illustrate an example response of a system defined as the integrated luminescence intensity for step changes in the concen-tration of oxygen that is detected by this gas detector. The most-advantageous detection range of the luminescence signal is a wavelength of $600 \mathrm{~nm}$ to $640 \mathrm{~nm}$, since the spectrum in this respect is most-sensitive to changes in the environment around the europium ions. 


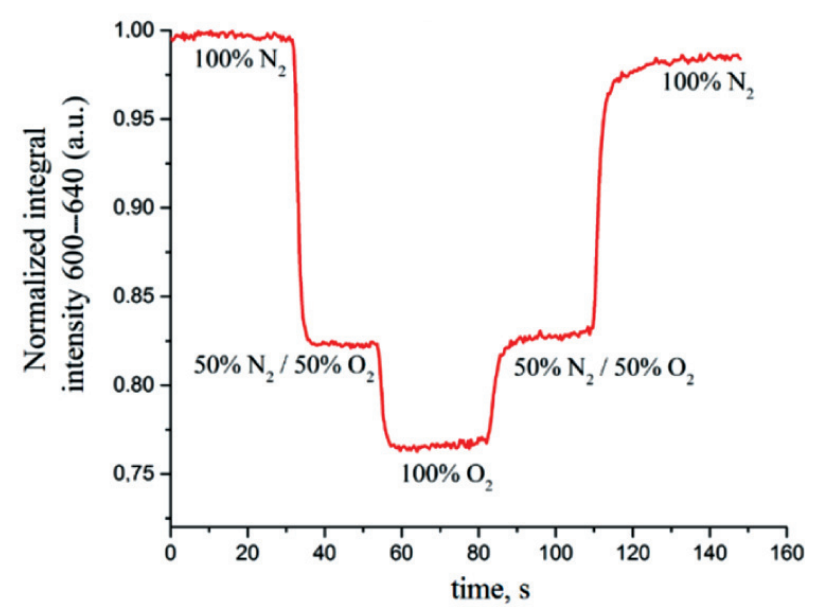

Fig. 7. Value of normalized integral of intensity of luminescence (in range of $600 \mathrm{~nm}$ to $640 \mathrm{~nm}$ ) during changes in oxygen content in measuring chamber shown in Figure 5

The changes in luminescence in the detection material as a result of the change in the composition of atmosphere occur over several dozens of milliseconds. The few seconds of rising or falling times of the recorded signal in the characteristic of Figure 7 result solely from the time of penetration of the gas under testing into the measuring chamber. The penetrating time will be shortened if the entrance tube (1) (shown in Fig. 5) is removed. The changes in the luminescence intensity integral value are not directly proportional to changes in the concentration of oxygen in the analyzed atmosphere. The detection material exhibits slightly higher sensitivity for oxygen concentrations of the order of a few to a dozen percentage points. This causes the $50 \%$ concentration of the luminescence concentration to not be halfway between the $0 \%$ and $100 \%$ concentration levels in Figure 7. An important sensory property of the nanocrystalline material depicted is the speed of its reaction to changes in the oxygen concentration in the atmosphere. The optical response time of the measurement system is less than several tens of milliseconds. This depends of the dynamics of the luminescence-quenching process in the nanomaterial. For industrial applications, the reaction time constant or time t90 depends only on the diffusion time or forced penetration of the gas into the inside of the measuring chamber and travel time through the dust filter. The diffusion penetration time or time constant are similar to methane detectors with infrared absorption - more than ten seconds.

\section{SUMMARY}

The research and development work done shows that the current technological level of thermoelectric modules allows them to be used as power-measuring devices. The conversion of heat to electricity can take place only where there is a heat flux (or one can be generated). Therefore, it is proposed to use an external measuring chamber that can be located at almost any distance from the stationary part. The use of photoluminescence in nanoscale zirconium dioxide doped with europium to measure oxygen concentration has completely eliminated the electrical components in the measuring chamber and optical signals between the chamber and stationary part of the device (which are transmitted only by optical fibers). The adopted way of self-calibration allows us to receive high stability and to avoid maintenance for many months. The results of the temperature tests (not presented in the paper) of the detection material indicate that its structural and chemical composition stability are within a temperature range of $-40^{\circ} \mathrm{C}$ to $300^{\circ} \mathrm{C}$. Thanks to this, the application field of the device under industrial conditions is very wide. The heat generated by the machines due to their imperfections and technological processes can be used for more than powering measuring instruments [2-4]. The concept of the measuring instrument adopted in the paper is the starting point for the construction of an industrial version of this device.

\section{References}

[1] Goldsmid H.J.: Introduction to Thermoelectricity, "Springer Series in Materials Science" 2016, 121: 1-24.

[2] Viswanathan V.V., Davies R.W., Holbery J.: Opportunity Analysis for Recovering Energy from Industrial Waste Heat and Emissions, Pacific Northwest National Laboratory, Richland 2006.

[3] Dunham M.T., Barako M.T., LeBlanc S., Asheghi M., Chen B., Goodson K.E.: Power Density Optimization for Micro Thermoelectric Generators, "Energy" 2015, 93: 20062017.

[4] Cao Z., Koukharenko E., Tudor M.J., Torah R.N., Beeby S.P.: Flexible screen printed thermoelectric generator with enhanced processes and materials, "Sensors and Actuators" 2016, 238: 196-206.

[5] Smits K., Grigorjeva L., Millers D., Sarakovskis A., Opalinska A., Fidelus J.D., Łojkowski W.: Europium doped zirconia luminescence, "Optical Materials" 2010, 32: 827-831.

[6] Polish Patent PAT.218574: Sposób pomiaru zawartości tlenu w gazie, http://regserv.uprp.pl/register/application?number $=$ P.393942. 
[7] European Patent EP2686669: Method of measuring of oxygen content in gas, https://register.epo.org/application?number= EP12715721.

[8] Yen W.M., Shionoya S., Yamamoto H.: Phosphor Handbook, CRC PRESS 2006.

[9] Lakowicz J.R.: Principles of Fluorescence Spectroscopy, Springer 2006.

ANDRZEJ NOWROT, Ph.D., Eng. MONIKA MIKOせAJCZYK, Eng. Department of Electrical Engineering and Automation in Industry Faculty of Mining and Geology Silesian University of Technology ul. Akademicka 2, 44-100 Gliwice, Poland andrzej.nowrot@polsl.pl monika.miko@onet.pl
KRZYSZTOF KAMIL ŻUR, Ph.D., Eng. Faculty of Management Engineering, Bialystok University of Technology ul. Wiejska 45A, 15-001 Biatystok, Poland Laboratory of Nanostructures Institute of High Pressure Physics

Polish Academy of Science ul. Sokołowska 29, 01-142 Warszawa, Poland k.zur@pb.edu.pl

WITOLD ŁOJKOWSKI, Prof. ANNA ŚWIDERSKA-ŚRODA, Ph.D., Eng. Laboratory of Nanostructures Institute of High Pressure Physics

Polish Academy of Science ul. Sokołowska 29, 01-142 Warszawa, Poland \{wl,annas\}@unipress.waw.pl 


\title{
Autonomiczny światłowodowy układ monitorowania stężenia gazów z zasilaniem termoelektrycznym
}

\begin{abstract}
$W$ artykule zostata przedstawiona koncepcja autonomicznego przyrzqdu pomiarowego zasilanego lokalnie dostępnym źródtem ciepła o powierzchni kontaktowej od kilkunastu do kilkudziesięciu centymetrów kwadratowych i temperaturze wyższej lub niższej od temperatury otoczenia o kilkanaście stopni Celsjusza. Opisano budowę i zasadę działania dwóch opracowanych $w$ toku dotychczasowych prac modutów: dedykowanego generatora termoelektrycznego małej mocy oraz luminescencyjnego, świattowodowego detektora gazów. Przeprowadzone badania wskazuja, że układ pomiarowy oparty na zaprezentowanej technologii będzie przez wiele miesięcy zdolny do ciagłego działania bez obstugi serwisowej.
\end{abstract}

Słowa kluczowe: gazometria, termoogniwo, nanotechnologia

\section{WSTEPP}

Włączenie do eksploatacji nowego urządzenia w sieci pomiarowej w warunkach przemysłowych wymaga zapewnienia odpowiedniego zasilania oraz interfejsu komunikacyjnego. W wielu przypadkach jest to kłopotliwe ze względu na potrzebę poprowadzenia nowej wiązki przewodów zasilających i teletransmisyjnych (po wykonaniu odpowiedniego projektu). Najdogodniejszym rozwiązaniem w przypadku urządzeń pomiarowych małej mocy, pracujących na powierzchni i otwartej przestrzeni, jest zastosowanie transmisji bezprzewodowej oraz hybrydowego zasilania wykorzystującego akumulatory i ogniwa fotowoltaiczne. Rozwiązanie to może zostać częściowo wykorzystane w podziemnej części kopalń z tą różnicą, że fotoogniwo zostanie zastąpione ogniwem termoelektrycznym. Najprostszy w zastosowaniu moduł termoelektryczny, dokonujący zamiany energii cieplnej w elektryczną, wykorzystuje do działania zjawisko Seebecka. Elementy tego typu są powszechnie stosowane w małych urządzeniach chłodniczych, w których zachodzi zjawisko Peltiera będące odwrotnością zjawiska Seebecka.
Ten sam moduł o nazwie handlowej „moduł Peltiera” może zostać zastosowany zarówno jako element chłodzący (jedna ze stron modułu ochładza się, a druga nagrzewa), jak i generator prądu elektrycznego w wyniku przepływu strumienia ciepła przez moduł na skutek zewnętrznie wymuszonej różnicy temperatur pomiędzy jego stronami. Zjawiska Peltiera i Seebecka są znane na płaszczyźnie fizyki od początków XIX wieku i zostały głębiej omówione m.in. w pracy [1, 2-4].

Część pomiarowa proponowanego urządzenia zostanie oparta na światłowodowym detektorze luminescencyjnym. Jest to element całkowicie nieelektryczny w miejscu dokonywania pomiaru, co jest bardzo istotne podczas pracy w atmosferze wybuchowej.

$\mathrm{W}$ artykule przedstawiono detektor tego typu dokonujący pomiaru zawartości tlenu w atmosferze OSE (Oxygen Sensor Effect). Jego zasada działania wykorzystuje unikatowe własności nanokrystalicznego dwutlenku cyrkonu domieszkowanego europem, otrzymanego za pomocą technologii mikrofalowej hydrotermalnej syntezy. Szczegółowe informacje na temat własności i otrzymywania tego nanomateriału zostały zawarte w pracy [5]. 
Wiązka światła UV o długości fali $405 \mathrm{~nm}$, padając na powierzchnię materiału detekcyjnego - pastylki nanocząstek $\mathrm{ZrO}_{2}: \mathrm{Eu}^{3+}$ ulega rozproszeniu. W widmie oprócz światła rozproszonego od powierzchni nanomateriału pojawia się dodatkowy sygnał o czerwonej barwie na granicy podczerwieni pochodzący od luminescencji w zakresie długości około 580-720 nm, którego intensywność zależy od stężenia tlenu. Wzrost zawartości tlenu w mieszaninie gazów/atmosferze powoduje spadek intensywności fotoluminescencji. Przedstawiony sposób pomiaru stężenia tlenu został zastrzeżony patentem krajowym oraz europejskim $[6,7]$.

\section{KONCEPCJA \\ CZUJNIKA ŚWIATKOWODOWEGO ZASILANEGO OGNIWEM TERMOELEKTRYCZNYM}

$\mathrm{Na}$ rysunku 1 przedstawiono schemat blokowy urządzenia pomiarowego zasilanego ogniwem termoelektrycznym z głowicą (komorą) pomiarową podłączoną do dwóch światłowodów. W toku dotychczasowych prac skonstruowano demonstratory najistotniejszych modułów urządzenia, w tym m.in.:

- generator termoelektryczny oparty na zjawisku Seebecka wraz z dedykowaną, stabilizowaną przetwornica DC/DC,

- światłowodowy, fotoluminescencyjny detektor gazu.

Zaprezentowany detektor światłowodowy stanowi jeden z niskoenergochłonnych układów pomiarowych, który może współpracować z opracowanym generatorem termoelektrycznym.

Pozostałe moduły - transmisji radiowej oraz mikrokontrolera o niskim poborze mocy zostaną oparte na elementach dostępnych w handlu i standardowo stosowanych w aparaturze przemysłowej. Układ stabilizatora napięcia zintegrowany z przetwornicą posiada dodatkowo kondensator typu „SuperCap” cechujący się wysoką pojemnością elektryczną.

Jego obecność umożliwi uzyskanie przez urządzenie chwilowej mocy elektrycznej wielokrotnie większej od wartości mocy ciągłej ogniwa termoelektrycznego (np. podczas radiowej transmisji paczki danych w trybie zwiększonej mocy/zasięgu). Praca kondensatora „SuperCap” będzie sterowana przez mikrokontroler za pomoca tranzystorów mocy. Niebieska ramką na schemacie z rysunku 1 oznaczono część stacjonarną urządzenia, która będzie instalowana/zabu- dowywana w miejscu, gdzie możliwe jest uzyskanie różnicy temperatur i strumienia ciepła.

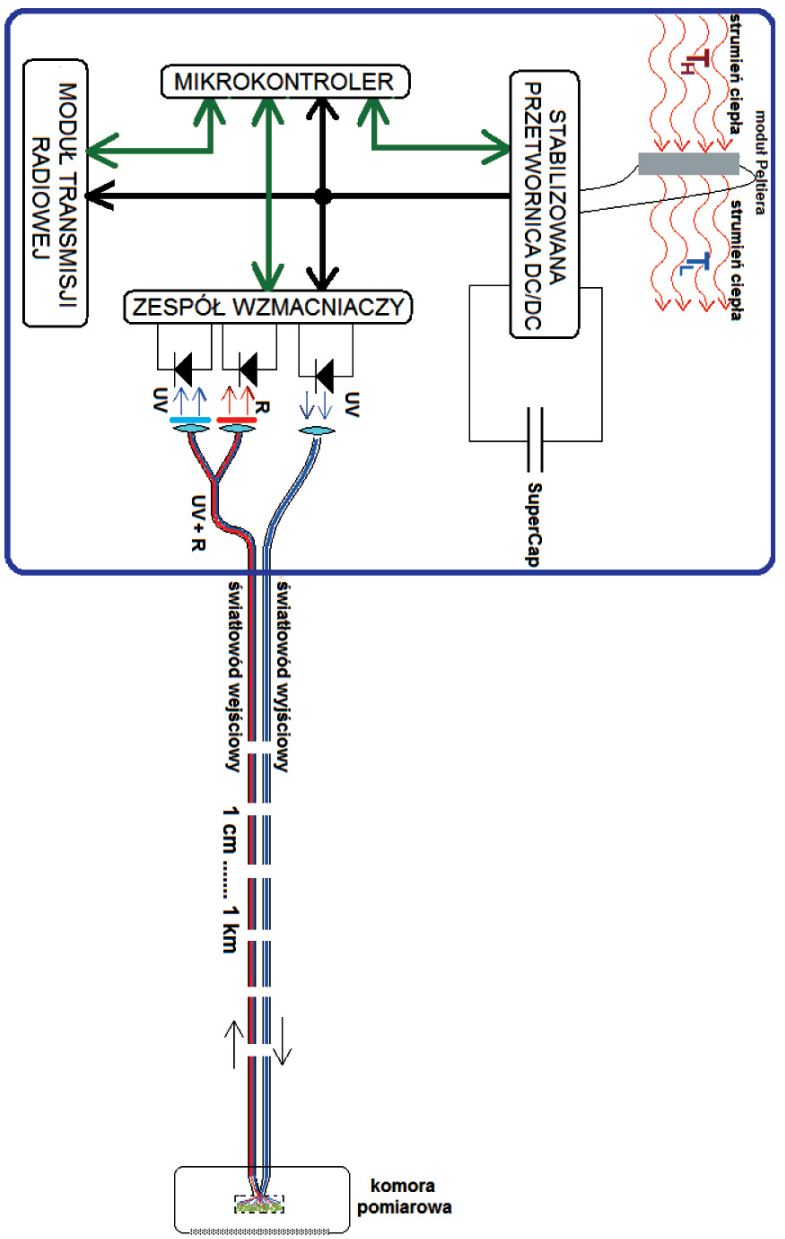

Rys. 1. Schemat blokowy urzadzenia pomiarowego zasilanego ogniwem termoelektrycznym z zewnętrzna świattowodowa komora pomiarowa

Komora pomiarowa zawierająca materiał detekcyjny, która jest połączona $\mathrm{z}$ członem stacjonarnym za pośrednictwem światłowodu, może być oddalona od niego o wiele metrów, a nawet kilometrów - w zależności od zastosowanego światłowodu. W eksperymentalnej wersji układu zastosowano światłowód wielowiązkowy o długości około $2 \mathrm{~m}$. Fala UV jest wytwarzana za pomocą diody LED UV $405 \mathrm{~nm}$.

Część detekcyjna składa się z dwóch fotodetektorów półprzewodnikowych poprzedzonych filtrami optycznymi. Pierwszy z nich dokonuje pomiaru światła w obszarze UV, które uległo uprzednio rozproszeniu w komorze pomiarowej na materiale detekcyjnym. Obszar czułości drugiego detektora obejmuje zakres 580-640 nm lub 600-640 nm i związany jest $\mathrm{z}$ fotoluminescencją powstającą $\mathrm{w}$ materiale detekcyjnym. Dzięki pomiarowi poziomu UV uzyskiwany jest sygnał odniesienia umożliwiający autokalibrację przyrządu niemal w dowolnej chwili. 


\section{OGNIWO TERMOELEKTRYCZNE NA BAZIE MODUŁU PELTIERA}

Konstrukcja generatora termoelektrycznego została oparta na możliwych do kupienia modułach Peltiera, które są przeznaczone głównie do urządzeń chłodniczych. Zastosowano trzy szeregowo połączone moduły o wymiarach $30,0 \mathrm{~mm} \times 30,0 \mathrm{~mm} \times 3,3 \mathrm{~mm}$ każdy. $\mathrm{Na}$ rysunku 2 przedstawiono zdjęcie w podczerwieni (kamerą termowizyjną) układu pomiarowego do wyznaczenia charakterystyk elektrycznych pojedynczego modułu jako generatora prądu elektrycznego. $\mathrm{Na}$ podstawie uzyskanych obrazów odczytano każdorazowo temperatury obydwu stron modułu Peltiera, w którym zachodziło zjawisko Seebecka.
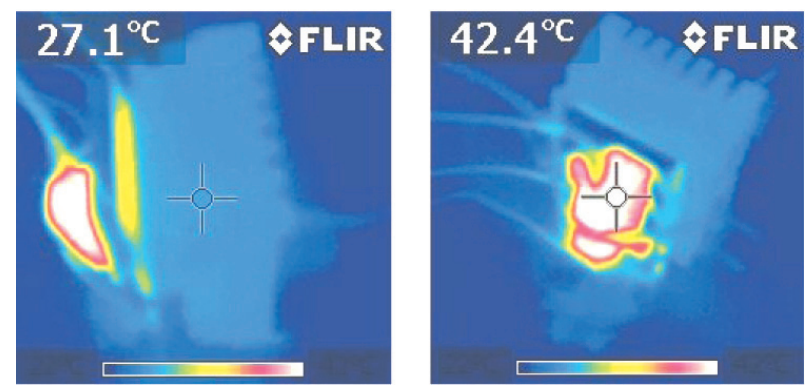

Rys. 2. Zdjęcia w podczerwieni układu pomiarowego do wyznaczenia charakterystyk elektrycznych pojedynczego modutu jako generatora prądu elektrycznego

Na rysunku 3 przedstawiono wyznaczoną elektryczną moc wyjściową pojedynczego modułu Peltiera pracującego jako termoogniwo dla różnych rezystancji obciążenia i różnicy temperatur pomiędzy ścianami modułu Peltiera wynoszącej $30,3^{\circ} \mathrm{C}$.

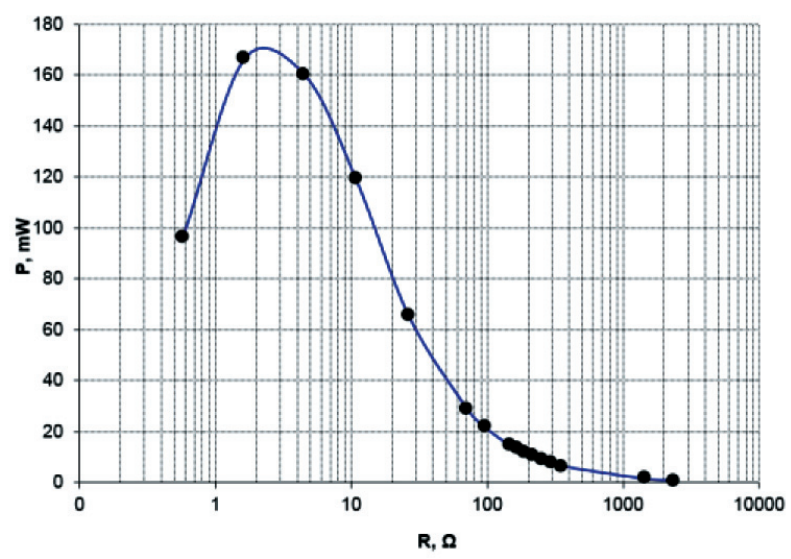

Rys. 3. Moc elektryczna ogniwa Peltiera podczas konwersji energii cieplnej na elektryczna dla różnych rezystancji obciążenia (wyniki dla różnicy temperatur pomiędzy stronami modutu $30,3^{\circ} \mathrm{C}$ )
Największa moc wyjściowa uzyskiwana jest dla rezystancji obciążenia z zakresu od $2 \Omega$ do $3 \Omega$. Niezbędne było opracowanie dedykowanej stabilizowanej przetwornicy DC/DC wyposażonej w zasobnik energii typu SuperCap, aby praca modułu odbywała się w otoczeniu jego maksymalnej mocy elektrycznej.

Maksymalna moc elektryczna uzyskiwana z modułu Peltiera na jednostkę jego powierzchni poprzecznej (przez którą prostopadle przenika strumień ciepła) podczas pracy jako termoogniwo, zależy silnie od różnicy temperatur pomiędzy jego stronami w sposób przedstawiony na rysunku 4.

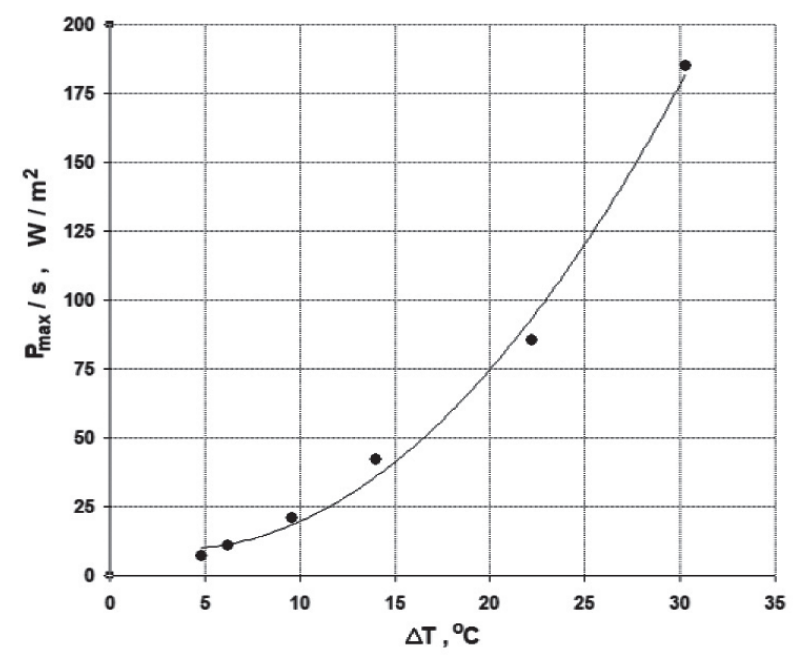

Rys. 4. Moc elektryczna wytwarzana przez jednostke powierzchni modutu Peltiera, w którym zachodzi

konwersja energii cieplnej na elektryczna w zależności od różnicy temperatur pomiędzy stronami modutu

W eksperymencie zastosowano jeden z modułów Peltiera o powierzchni $9 \mathrm{~cm}^{2}$. Przeprowadzone pomiary wskazują, że obecny poziom technologiczny produkowanych modułów Peltiera pozwala na wytworzenie dla różnicy temperatur ok. $30^{\circ} \mathrm{C}(\mathrm{K})$ pomiędzy jego stronami, mocy elektrycznej ponad $180 \mathrm{~W} / \mathrm{m}^{2}$. Jest to wartość porównywalna $\mathrm{z}$ mocą elektryczną (powierzchniową gęstością mocy) fotoogniw dostępnych w handlu. Dla punktów pomiarowych z rysunku 4 przeprowadzono aproksymację wielomianem drugiego stopnia oraz funkcją potęgową:

$$
\frac{P_{\max }}{s}=A \cdot \Delta T^{2}+B \cdot \Delta T+C
$$

gdzie:

$$
\begin{aligned}
& A=0,24(0,04) \mathrm{W} /\left(\mathrm{m}^{2} \cdot \mathrm{K}^{2}\right), \\
& B=-1,7(1,5) \mathrm{W} /\left(\mathrm{m}^{2} \cdot \mathrm{K}\right), \\
& C=13(10) \mathrm{W} / \mathrm{m}^{2} .
\end{aligned}
$$




$$
\frac{P_{\max }}{s}=A \cdot \Delta T^{B}
$$

gdzie:

$$
\begin{aligned}
& A=0,16(0,08) \mathrm{W} /\left(\mathrm{m}^{2} \cdot \mathrm{K}^{\mathrm{B}}\right), \\
& B=2,07(0,16) \log _{\mathrm{k}}\left(\mathrm{W} \cdot \mathrm{m}^{2} \cdot \mathrm{A}^{-1}\right) .
\end{aligned}
$$

Zważywszy na wysoką niepewność wartości niektórych współczynników w równaniach (1) i (2), można jedynie stwierdzić, że uzyskane obydwa dopasowania wskazują wyraźnie na charakter zależności: $\frac{P_{\max }}{s} \sim \Delta T^{2}$.

\section{FOTOLUMINESCENCYJNY DETEKTOR GAZU}

Komora pomiarowa urządzenia jest elementem całkowicie nieelektrycznym. Na rysunku 5 przedstawiono demonstrator komory, który stanowi punkt wyjścia do budowy jego przemysłowej wersji. Analizowany gaz wnika do wnęki detekcyjnej przez rurkę o średnicy $4 \mathrm{~mm}$. Proces ten może odbywać się w sposób wymuszony przez wtłaczanie mieszaniny gazów lub samoczynnie (dyfuzyjnie).

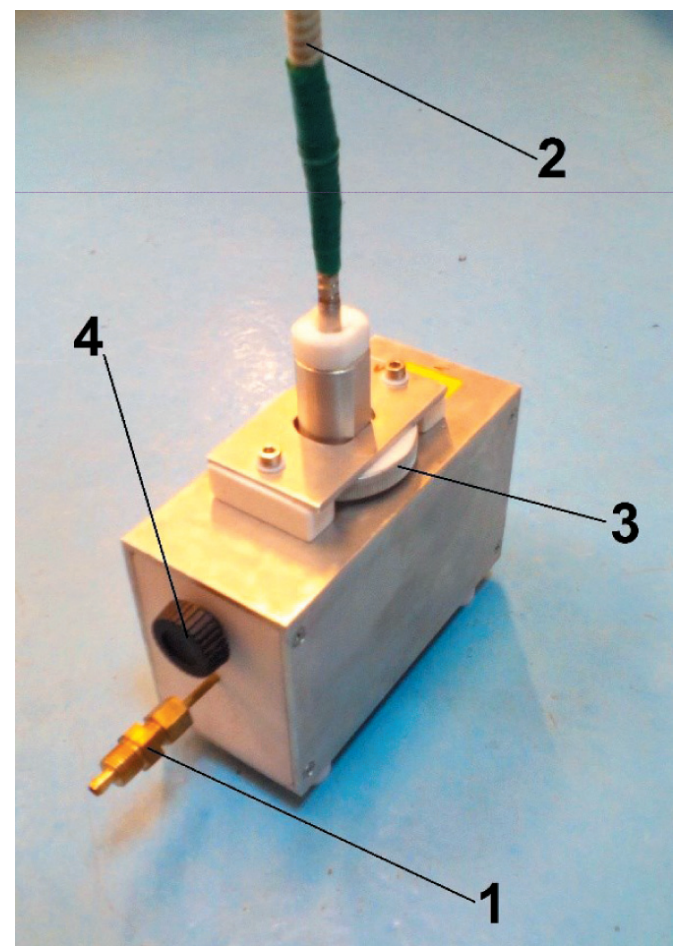

Rys. 5. Komora pomiarowa: 1 - wlot mierzonego gazu,

2 - pancerz świattowodów, 3 i 4 -śruby kalibracyjne.

Wymiary zewnętrzne prostopadłościennej części komory: $170 \mathrm{~mm} \times 100 \mathrm{~mm} \times 70 \mathrm{~mm}$
W zależności od ustawienia elementów kalibracyjnych komory właściwy proces detekcji dokonywany jest we wnęce o objętości około $1 \mathrm{~cm}^{3}$. W przemysłowej wersji urządzenia dokonane zostanie radykalne zmniejszenie wymiarów zewnętrznych komory oraz zastąpienie rurki wlotowej płaskim filtrem ze spieku ceramicznego na obudowie, co pozwoli znacznie skrócić czas dyfuzyjnego wnikania gazu do wnętrza komory. Również materiał, z którego została wykonana obudowa (stal nierdzewna), zostanie docelowo dostosowany do wymogów pracy w atmosferze wybuchowej, tzn. uderzenie dowolnym przedmiotem $\mathrm{w}$ obudowę urządzenia nie może wytworzyć iskry. Do komory z rysunku 5 podłączono dwie grupy włókien światłowodowych zgodnie z ideą przedstawioną na rysunku 1 . Zawarte są one w jednym pancerzu - pozornie można odnieść wrażenie, że podłączony został tylko jeden światłowód.

Materiał detekcyjny - nanoproszek $\mathrm{ZrO}_{2}: \mathrm{Eu}^{3+}$ (5\% mol) ma postać pastylki (uzyskanej w wyniku sprasowania) o średnicy $7 \mathrm{~mm}$ i grubości $0,2 \mathrm{~mm}$. Nanocząstki zawarte w pastylce mają wymiary średnio ok. $10 \mathrm{~nm}$. Światło UV powoduje fotoluminescencję w materiale detekcyjnym o poziomie zależnym od stężenia tlenu. Na rysunku 6 przedstawiono przykładowy przebieg sygnału luminescencji materiału detekcyjnego umieszczonego $\mathrm{w}$ komorze $\mathrm{z}$ rysunku 5 i oświetlonego światłem o długości fali $405 \mathrm{~nm}$. Położenie poszczególnych ekstremów odpowiada barwie czerwonej oraz fragmentowi bliskiej podczerwieni.

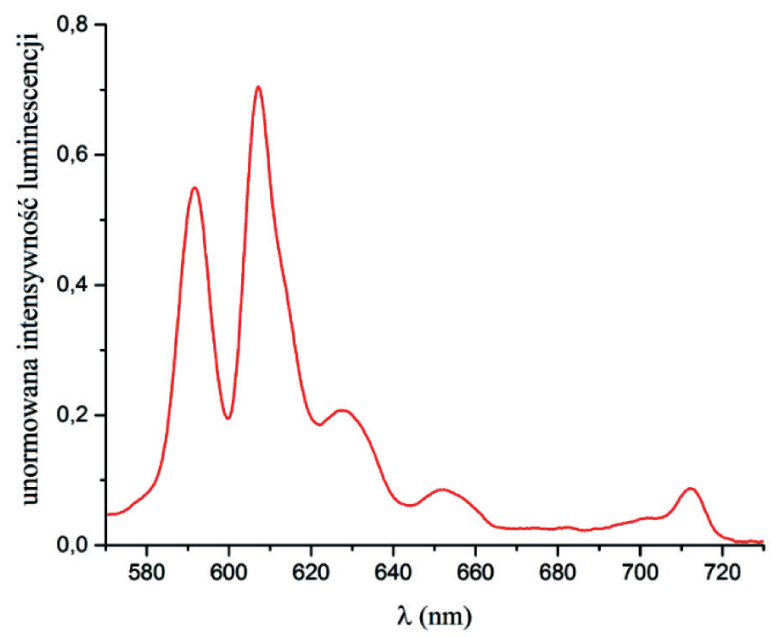

Rys. 6. Sygnat luminescencji pastylki $\mathrm{ZrO}_{2}: \mathrm{Eu}^{3+}$ uzyskany $w$ atmosferze laboratoryjnej (bez przepływu gazu, w temperaturze pokojowej) [5]

Wynika ono z przejść elektronowych charakterystycznych dla jonów $\mathrm{Eu}^{3+}$ umieszczonych w matrycy 
nanokrystalicznego $\mathrm{ZrO}_{2}$. Wysokość pików oraz wartość pola figury pod krzywą na wykresie z rysunku 6 w przyjętym zakresie (całka oznaczona intensywności luminescencji) zależy od stężenia tlenu i stanowi sygnał mierzony w stacjonarnej części urządzenia. W zależności od zastosowanego filtru optycznego wykonano pomiar w zakresie od $580 \mathrm{~nm}$ do $640 \mathrm{~nm}$ lub od $600 \mathrm{~nm}$ do $640 \mathrm{~nm}$.

Charakterystyka z rysunku 7 przedstawia przykładową odpowiedź układu zdefiniowaną jako całkę intensywności luminescencji na skokowe zmiany stężenia tlenu, który jest dla tego detektora mierzonym gazem. Najkorzystniejszy zakres detekcji sygnału luminescencji obejmuje długości fali od $600 \mathrm{~nm}$ do $640 \mathrm{~nm}$, gdyż widmo w tym zakresie jest najbardziej czułe na zmiany otoczenia wokół jonów europu $[8,9]$.

Zmiana luminescencji materiału detekcyjnego w wyniku zmiany składu atmosfery otaczającej go następuje w czasie kilkudziesięciu milisekund. Kilkusekundowe czasy narastania lub opadania rejestrowanego sygnału $\mathrm{w}$ charakterystyce $\mathrm{z}$ rysunku 7 wynikają wyłącznie z czasu wnikania badanego gazu do wnętrza komory pomiarowej. Rezygnując z rurki wejściowej (1) (przedstawionej na rysunku 5), czas ten ulegnie wyraźnemu skróceniu. Zmiana wartości całki intensywności luminescencji nie jest wprost proporcjonalna do zmian stężenia tlenu w analizowanej atmosferze.

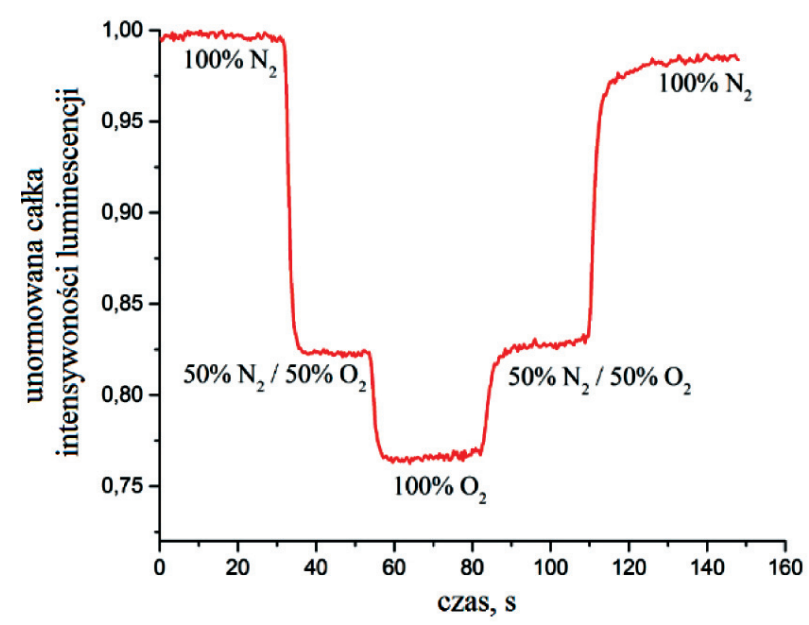

Rys. 7. Wartość unormowanej catki z intensywności luminescencji ( $w$ zakresie 600-640 $\mathrm{nm}$ ) podczas zmian stężenia tlenu w komorze pomiarowej z rysunku 5

Materiał detekcyjny wykazuje nieco większą czułość dla stężeń tlenu rzędu kilku i kilkunastu procent. Powoduje to, że wartość całki intensywności luminescencji dla stężenia tlenu $50 \%$ nie jest położona $\mathrm{w}$ połowie pomiędzy poziomami odpowiadającymi stężeniom $0 \%$ i $100 \%$ na rysunku 7. Istotną własnością sensoryczną przedstawionego materiału nanokrystalicznego jest szybkość jego reakcji na zmianę stężenia tlenu w otaczającej atmosferze. Czas optycznej odpowiedzi układu pomiarowego wynosi nie więcej niż kilkadziesiąt milisekund, co wynika z dynamiki procesu wygaszania luminescencji $\mathrm{w}$ nanomateriale. $\mathrm{Z}$ aplikacyjnego punktu widzenia stała czasowa lub czas $t_{90}$ reakcji przyrządu zależą wyłącznie od czasu dyfuzyjnego lub wymuszonego wnikania analizowanego gazu do wnętrza komory pomiarowej oraz czasu przenikania przez filtr przeciwpyłowy. Dla wnikania dyfuzyjnego stała czasowa jest podobna do istniejącej w metanomierzach wykorzystujących absorpcję w podczerwieni, czyli kilkanaście sekund.

\section{PODSUMOWANIE}

Przeprowadzone prace badawcze i konstruktorskie wskazują, że obecny poziom technologiczny ogniw termoelektrycznych pozwala na ich zastosowanie do zasilania urządzeń pomiarowych. Konwersja energii cieplnej na elektryczną może odbywać się jedynie w miejscach, gdzie występuje lub można wytworzyć strumień ciepła. W związku z tym zaproponowano zastosowanie zewnętrznej komory pomiarowej, która może znajdować się niemal w dowolnej odległości od części stacjonarnej. Wykorzystanie zjawiska fotoluminescencji w nanokrystalicznym dwutlenku cyrkonu domieszkowanym europem do pomiaru stężenia tlenu pozwoliło całkowicie wyeliminować elementy elektryczne w komorze pomiarowej, a sygnały optyczne pomiędzy komorą i częścią stacjonarną urządzenia są przesyłane wyłącznie światłowodami. Przyjęty sposób autokalibracji pozwala na uzyskanie wysokiej stabilności pracy i uniknięcie serwisowania przez wiele miesięcy. Wyniki badań temperaturowych (nie zostały przedstawione $w$ niniejszym artykule) materiału detekcyjnego wykazują jego stabilność strukturalną i chemiczną w zakresie od $-40^{\circ} \mathrm{C}$ do $300^{\circ} \mathrm{C}$. Dzięki temu obszar aplikacyjny urządzenia $\mathrm{w}$ warunkach przemysłowych jest bardzo szeroki. Energia cieplna, która wydziela się w maszynach na skutek ich niedoskonałości oraz $\mathrm{w}$ procesach technologicznych, może zostać wykorzystana nie tylko do zasilania przyrządów pomiarowych [2-4]. Przyjęta w referacie koncepcja przyrządu pomiarowego jest punktem wyjściowym do budowy przemysłowej wersji urządzenia. 
Literatura

[1] Goldsmid H.J.: Introduction to Thermoelectricity, „Springer Series in Materials Science" 2016, 121: 1-24.

[2] Viswanathan V.V., Davies R.W., Holbery J.: Opportunity Analysis for Recovering Energy from Industrial Waste Heat and Emissions, Pacific Northwest National Laboratory, Richland 2006.

[3] Dunham M.T., Barako M.T., LeBlanc S., Asheghi M., Chen B., Goodson K.E.: Power Density Optimization for Micro Thermoelectric Generators, „Energy” 2015, 93: 2006-2017.

[4] Cao Z., Koukharenko E., Tudor M.J., Torah R.N., Beeby S.P.: Flexible screen printed thermoelectric generator with enhanced processes and materials, „Sensors and Actuators” 2016, 238: 196-206.

[5] Smits K., Grigorjeva L., Millers D., Sarakovskis A., Opalinska A., Fidelus J.D., Łojkowski W.: Europium doped zirconia luminescence, „Optical Materials” 2010, 32: 827-831.

[6] Patent polski PAT.218574: Sposób pomiaru zawartości tlenu w gazie, http://regserv.uprp.pl/register/application?number $=\mathrm{P} .393942$.

[7] Patent europejski EP2686669: Method of measuring of oxygen content in gas, https://register.epo.org/application?number $=\mathrm{EP} 12715721$.

[8] Yen W.M., Shionoya S., Yamamoto H.: Phosphor Handbook, CRC PRESS 2006.

[9] Lakowicz J.R.: Principles of Fluorescence Spectroscopy, Springer 2006. dr inż. ANDRZEJ NOWROT

inż. MONIKA MIKOEAJCZYK

Katedra Elektrotechniki i Automatyki Przemystowej

Wydziat Górnictwa i Geologii

Politechnika Ślaska

ul. Akademicka 2, 44-100 Gliwice andrzej.nowrot@polsl.pl monika.miko@onet.pl

dr inż. KRZYSZTOF KAMIL ŻUR

Wydziat Inżynierii Zarzadzania Politechnika Białostocka

ul. Wiejska 45A, 15-001 Biatystok Laboratorium Nanostruktur

Instytut Wysokich Ciśnień PAN ul. Sokołowska 29, 01-142 Warszawa k.zur@pb.edu.pl

prof. dr hab. WITOLD ŁOJKOWSKI dr inż. ANNA ŚWIDERSKA-ŚRODA

Laboratorium Nanostruktur Instytut Wysokich Ciśnień PAN ul. Sokołowska 29, 01-142 Warszawa $\{w l$,annas\}@unipress.waw.pl 